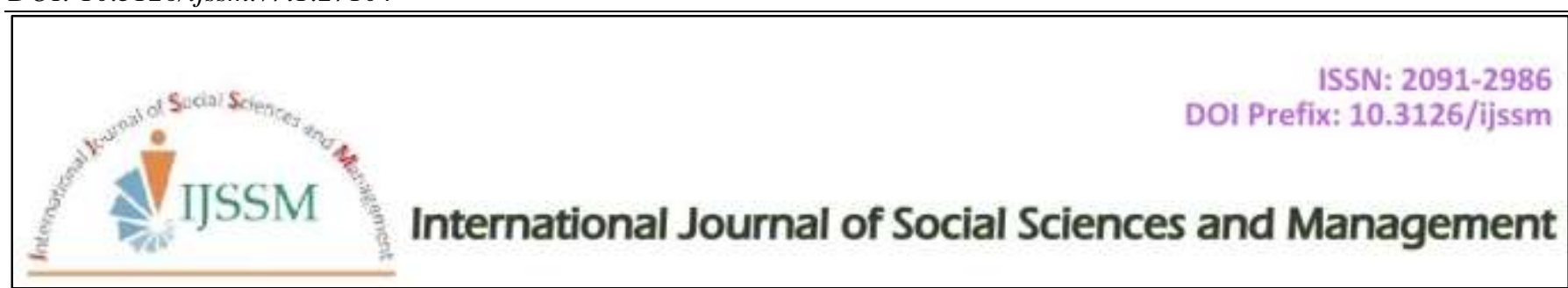

Research Article

\title{
Leaderships in the Global South: On BP Koirala's Economic Thinking
}

\author{
Ratna Mani Nepal \\ Central Department of Rural Development, Tribhuvan University, Kirtipur, Nepal
}

\section{Article Information}

Received: 15 December 2019

Revised version received: 21 January 2020

Accepted: 22 January 2020

Published: 27 January 2020

\section{Cite this article as:}

R.M. Nepal (2020) Int. J. Soc. Sc. Manage. 7(1): 21-29.

DOI: $\underline{10.3126 / \text { ijssm.v7i1.27104 }}$

\section{*Corresponding author}

Ratna Mani Nepal,

Central Department of Rural Development, Tribhuvan

University, Kirtipur, Nepal

Email: rmn@cdrd.edu.np

Peer reviewed under authority of IJSSM

(C) 2020 International Journal of Social Sciences and Management

\section{OPEN ACACESS}

This is an open access article \& it is licensed under a Creative Commons Attribution Non-Commercial 4.0 International (https://creativecommons.org/licenses/by-nc/4.0/)

\begin{abstract}
Political leaderships in the global south emerged in course of anti-colonial movements or movements against domestic authoritarianism. The leaderships in these liberation movements also laid foundation for social and economic development of the respective countries, besides political transformation. This article analyzes economic thinking of BP Koirala of Nepal, who led the land-locked country to transform from Rana oligarchy to political democracy. Information by interviews and narrative analysis show that BP's economic perspectives were in germinal form, though he discussed on varieties of issues such as industrialization, land reform, tax, foreign aid, technology and planning. BP's concept on these economic issues represent desire and aspirations of a land-locked underdeveloped country Nepal in the fifties, which was about to relieve it from Rana oligarchy and embark into socio-economic modernization. His ideas were contextual that refer to his ideals of democracy and socialism and his affiliation with foreign leaderships and institutions. Besides the pursuit of economic development, BP's views on economy represent his political strategies to counteract feudal social and political order, seek his leadership's legitimacy, and build a broader coalition for political objectives. Nevertheless, BP's economic views seem to be people centric and hence tend to influence governments as prescription policies.
\end{abstract}

\section{Background}

Political leaderships in the global south emerged during the liberation movements organized to end foreign colonial rule or domestic despotism. W. Howard Wriggins (1970) has analyzed these leaderships in terms of the strategies they used to aggregate power and to build supporting coalitions to achieve their goals ${ }^{1}$. Structural analysis e.g. analysis of politics, economy, law, and social norms has also been adopted to study the leaderships (Rustow, 1970). Dettman (1974) has attempted to relate comparatively the legitimacy aspect of leadership with structural variables to analyze leaderships in some countries in the global south. These leaderships ensured legitimacy in many senses in that they had rich traditions, commitment to political transformation and perspectives of social and economic development of their homeland.

\footnotetext{
${ }^{1}$ According to W. Howard Wriggins the strategies used by the leaderships in the Third World (Global South) were; projecting personality, building an organization, formulating an ideology, providing patronage,
} 
South's leaderships have diverse political orientations; however, they stand common while putting views on economic transformation. Gandhi of India was critical to western civilization as he denied the application of industrialization, urbanization, and technology to generate economy of sufficient need. He preferred Village Swaraj, self-reliant villages, absolutely endowed with basic requirements for economy, society, and governance (Namita, 2014). In Tanzania, the first democratic president, Julius Nyerere, had similar views as Gandhi had in that he rejected even foreign aid because it could spoil 'African values' and augment dependency. Mao Tse Zung of China opposed western capitalism, vowed the importance of Chinese values, and founded the political economy of Maoism. In common, these leaderships confirmed to the ideals of self-reliance, decentralization, local values, and people-centric approach of change. They were critical to western modernity and envisioned 'alternative' pathways to prosperity for their country ${ }^{2}$.

The alternative course taken by the south's leaderships seems to be a response to the evolving cold war between two ideologies; liberal capitalism and communism. The reaction yielded a movement by the south's (Afro-Asian) leaderships called 'Non Alignment Movement (NAM)' in 1956 (Rist, 2006). That period, socialist political parties in Asia formed Asian Socialist Conference (ASC) that held its first conference in 1953 in Myanmar. Ideologically, this foundation was a body of anti-capitalist, non-aligned, and non-Eurocentric world-view that offered 'socialism with Asian Characteristics' (Zande, 2017). Some leaders of these foundations themselves executed their ideas after being ascending to the government; others remained in the opposition, but continued to influence national policy patterns.

This time around in land-locked country Nepal, BP Koirala's leaderships emerged. He founded Nepali Congress Party, socialist in orientation, in 1946 and vowed democracy, socialism and development. He had connections with prominent anti-colonial movement leaders Mohandas Karamchandra Gandhi (India), Mao Tse Zung (China), J. Nehru, J.P. Narayan and R.M Lohiya of India. BP's membership in Socialist International (SI) had resulted in his friendship with global socialist leaders including Willy Brandt, former German Chancellor (Chatterji, 1982). $\mathrm{BP}$ was one of the initiators of Asian Socialist Conference (ASC) and participated in the first conference in Myanmar

${ }^{2}$ For more detail on the development perspectives of leaderships in the global south see my PhD thesis entitled 'Alternative Development Perspectives and Trends in the Global South: With Special Reference to Social Democratic Thoughts of BP Koirala, Nepal', 2018, Tribhuvan University.

${ }^{3}$ Documents related to Asian Socialist Conference are available at; https://www.cia.gov/library/readingroom/docs/CIA-RDP78-

00915R000500160005-4.pdf
$(1953)^{3}$. After ousting the century old despotic Rana regime, BP led the country as a home minister in 1952 and prime minister in 1959-1960. Rest of the time he remained in the opposition and continued his ideological legacy.

This article analyzes BP Koirala's narratives and information sought from key respondents ${ }^{4}$ to analyze his economic thinking and answer questions such as; what aspects of economy BP discussed and whether his economic thinking was strategy or legitimacy of his leadership.

\section{Economy and Economic Development by BP Koirala}

BP Koirala's political economic thoughts emerged concurrently with the foundation of Nepali Congress by himself in India in 1946. They appeared in the political documents BP published on various occasions to appeal broader Nepali masses in India and Nepal. Over the time, his ideas evolved, embraced elements of contemporary importance, and sharpened. While in positions, ${ }^{5} \mathrm{BP}$ mobilized state machinery to execute his views towards his political objectives. As he was in opposition, he continued communicating his opinions on economy and economic development through writings, memoirs, speeches, and interviews on various occasions. Overall, BP's economic thoughts comprised his views on industrialization, land reform, foreign aid, tax, technology, decentralization, and dynamics of production.

Importantly, BP's ideas on economy and economic development have some ideological bases that he expressed metaphorically. First, BP envisioned a fully developed democratic society to be able to acquire the principles of socialism. He held that political democracy is a mere necessary condition; sufficient is economic democracy. Secondly, BP believed that economy should have national roots; meaning that, as Gandhi, Mao and Nyerere argued, pattern of economic transformation needed a local base, in terms of resources and objectives, both. Thirdly, BP argued that state should act as a guardian to enable its pupils to participate in equity based participatory production process. He explained state as the leader and the people, and associated state organs together would make a whole family. The state would create enabling environment for its pupils to exercise fully their capacity to gain from their labor and acquires in return some part from them. Dimensions of Economy and their Explanations are shown in Table 1.

${ }^{4}$ The key respondents are Biswabandhu Thapa, Pursottam Basnet, Chandraprakash Mainali, Baladev Majgaiyan, Ram Sharan Mahat, Narahari Acharya, Govinda Adhikari and Krishna Bahadur Kunwar.

${ }^{5}$ In 1952 and in 1959-60, BP was in the positions of Home Minister and Prime Minister respectively. 
Table 1: Dimensions of Economy and their Explanations

\begin{tabular}{|l|l|}
\hline Dimensions & Major Explanation \\
\hline Industrialization & Modernization \\
\hline Land reform, Agriculture development, and Rural development & Economic justice, modernization \\
\hline Tax & National capital, equality, and Justice \\
\hline Foreign Aid & External sources and Inter-dependency \\
\hline Appropriate technology and renewable energy & Sustainability \\
\hline Development planning & Participatory \\
\hline Source: Author &
\end{tabular}

\section{Industrialization}

BP Koirala held the view that a sustainable economic development needed a sound industrial base. He has highlighted the significance and role of industrialization in Nepal for two basic causes; a) expanding the capacity of the country's economy, and b) ending the feudal base of Nepali society.

BP believed that sole dependence on land for Nepal's development could be costly. The revenue from the land alone could not sustain its nascent economy. He argued that meeting the goal of fair socialism is risky if the country relies on production and growth merely from the landeconomy. Hence, industrial sector is a viable alternative source for country's economic development. BP opined that industry is the most productive sector of an economy in terms of generating jobs, distributing wealth and mobilizing local resources (Basnet, 2017, p. 613).

$\mathrm{BP}$ held that industrial development is necessary in order to increase the stock of national capital. BP said 'national capital could be outsourced from foreign aid, profit of industries and factories, individual saving, progressive tax, and growth in national income (Basnet, 2017, p. 507-08). He opined that acquiring wealth from the industries and factories would need high export of produces in comparison to import. He emphasized export at the cost of controlled import so that state could increase its wealth. The stock of the wealth could strengthen government capacity to mobilize for the need of people.

As the prime minister, BP evoked that industrialization is means to catch up the progress of developed countries. He said that 'Nepal need catching up the path of development within ten to fifteen years, which the developed-industrialist countries achieved in more than hundred years' (Acharya, 2001, p. 26; Joshi \& Rose, 2006, p. 353). He said that the target could have been possible if industrialization proceeded along.

BP envisaged industrialization process in harmony with social modernization. More than making an economy vibrant, the industrial society could influence society and its culture. In a speech delivered in the parliament on June 10, 1960 , he argued that cast issues, the issues of untouchability rooted in Nepali society could be ameliorated if industrialization was properly planned. BP said, 'neither the laws nor the constitutional bodies solve the cast issues but the industrialization can' (Nepal, 2010, p. 170).

BP offered an example of a shoe industry. He believed that a fully functioning industry could demand both raw materials as well as labors. A traditional shoemaker, who is supposed to be low cast and untouchable, has high chance to be a worker in a shoe factory. Youths from pundit's family could get job as accountant or manager. Someone else starts a small teashop around. Then people in the society, including the so-called upper caste, gather around the shoe industry, they sit, eat and work together with lower cast workers. After few meetings, gradually they will forget that they belong to higher and lower cast and that it is impure to touch the low cast shoemaker. Referring this example, BP held the view that 'the social and cultural dogma could be changed through industrialization' (Giri, 2009, p. 116). He envisaged that Nepal needed not only the land reform-based social justice but equally important was industrialization to address social inequalities.

Industries could also get farmers rid of age-old long suppression and hard life. BP held the view that feudal land order had been harsh to the farmers who actually work in the land. The condition of small farmers was highly critical due to unequal land tenure system. This could have been abolished and farmers freed if land-based-economy was supplemented by industrial economy. This way, farmers could jump from agriculture labors to the industrial workers for their livelihood. The modern industrial sector could exploit low than the traditional agriculture sector.

The pattern of industrial growth BP deemed varies with the change of time-space and his political positions. During the 1950 's revolution until his premiership tenure, he envisioned industries of all scales and higher production capacities. In Nepali Congress's Manifesto (1950), BP mentioned that Nepal needed big industries and technologies to embark on to modernization. As a prime minister in 1959, he heartily welcomed foreign investment in the industries of all scale such as cigarette, match, sugar, and cement. Yet, priority was also given to the promotion of small industries. 
Table 2: BP's Concept of Industrialization over Time

\begin{tabular}{|l|l|l|l|}
\hline Theme of Analysis & Conceptual explanation & \multicolumn{2}{|l|}{ Time Period } \\
\cline { 3 - 4 } & & $\mathbf{1 9 5 0 - 6 0}$ & $\mathbf{1 9 7 0 - 8 0}$ \\
\hline Industry & Form & Big+Small & Small \\
\hline Objectives & End of Feudalism & Yes & - \\
& Justice to the farmers & Yes & Yes \\
& National Capital & Yes & - \\
& Employment/Economic opportunities & Yes & Yes \\
& Social modernization & Yes & Yes \\
& Peoples Participation & Yes & Yes \\
\hline Agencies & State & Yes & No \\
& Private Sector & Yes & Yes \\
\hline Means/Methods & Technology transfer & No & No \\
& Foreign aid & Yes & No \\
& Special Economic Zone & Yes & No \\
\hline
\end{tabular}

In the Second Five Year Plan (1961-65) proposed by BP's government, industrialization received a top priority. The industrial sectors including transportation, roads, and electricity received one hundred and thirty-five million budget of the total, whereas agriculture received seventeen million rupees. The plan envisaged industrial zones in Kathmandu and Hetauda. Policies were formulated to set up agro-based and cottage industries in different parts of the country.

Latter during the 1980s, when he was in opposition, BP firmly conformed to small and cottage industries backed by agricultural resources. He consistently advocated the significance of rural economy based on cottage industries. He believed that those industries should be run by the people with small capital so that participatory industrialization was possible. He termed it as 'local innovative investment' (Giri, 2009, p. 116) that could make the process of industrialization self-reliant. He held that village development is possible only by industrializing the villages (Table 2).

Devendra Raj Pandey (Personal Interview, 1/17/2018) observed that BP's turn from high-scale industrialization to small technologies was his ideological shift from Marxism to Gandhism. He said after 1976, BP fully succumbed to E. F. Schumacher's idea of 'Small is Beautiful'. Being influenced by Schumacher, BP subscribed to Gandhi's principles of development and favored local and small industries.

However, BP Koirala's views on industrialization are asymmetrical to Gandhian notions (Acharya, 2001, P: 6896). He argued that Gandhian views on village industrialization could be unable to solve caste based discrimination and issues in exclusive society. He believed that industrial base in a society means a new social order conforming to modernity. It could wipe out conservative social values and establish modern institutions. However, BP argued, Gandhian way could institutionalize and continue old traditions and social order. It was not acceptable to him.

Krishna Bahadur Kunwar (Personal Interview, 12/26/2017) opined that change in BP's perception was symmetrical with changes in international development paradigms. He said development discourse after 1970 took a turn from highscale industrialization, technology transfer, and growth to rural and agriculture development, environment protection, and basic need that put people at the center. Kunwar said that as an astute observer of local and international trends, BP took a shift in his thinking. According to Ram Sharan Mahat (Personal Interview, 10/18/2017), though BP changed in his tone regarding industrialization and opted rural industries and technology, he consistently emphasized productive capacity of the economy. He meant that capital investment was still BP's priority in the later period.

\section{Agencies for Industrialization}

BP Koirala has discussed both public as well as private sectors as players to accelerate the pace of industrialization. He said that government could bear the responsibility of industrialization. BP opined that 'running a democratic state is like managing a family' (Koirala, 2015, p. 188). It was all depended on state's responsibility, accountability, and the rule it sets to be followed by its people for earning their livelihood. As such, the people could involve their capacities to generate as much economy they could, which they would pay back to the state in the form of tax to contribute to its managerial function. According to Bishwabandhu Thapa (Personal Interview, 2/3/2018), while he was prime minister BP planned huge investment in public goods such as roads, education, and health. He wanted the public sector to be dynamic and responsible guardian of overall state affairs including the industries.

With regard to the significance of private sector, BP held the view that low capacity of the public sector could be supplemented by encouraging the private sector. He envisaged private sector as the promoter of growth. He assumed that private capital could advance 
industrialization. Promotion of national and local investment is possible if people are encouraged to invest in their priority sectors. Ram Sharan Mahat (Personal Interview, 10/18/2017) argued that BP was in favor of stateleadership in the process of development. He said that BP aimed at strengthening people's capacity to do better in every respects of their livelihood including businesses. This way under the government's leadership, people's businesses (private sector) could flourish. In view of Jagadish Chandra Pokharel (Personal Interview, 1/25/2018), BP envisaged an economy where played state, people, and local resources, of which people occupy the center. Pokharel explained that people's mobilization for the sake of development meant encouraging the private sector. He argued that if state were a public sector, people would become private agencies.

During the period of BP's government (1959-1960), both local and foreign investors were encouraged to mobilize investment in the country's potential sectors. In his official visit to India in November 1960, BP offered the Indian Industrialists to divert investment in Nepal. He committed before them that government could waive tax on profit for at least ten years and provide peace and security for their businesses. He also promised that the Indian industrialists could bring back the profit in their own country. BP's motive to encourage privatization could also be seen in that he favored internal resource mobilization for industrialization. He was anxious with the capital flight that had been in practice since the time of Rana regime. BP argued that industrialization could save people's money that can be further utilized to generate entrepreneurships in various sectors.

\section{Foreign Aid}

BP's views on foreign aid are highly compatible with the views of Asian Socialist Conference (ASC), of which he was an active participant. BP believed that underdeveloped countries require foreign aid since they lack enough resources to meet the goals of economic development. As a premier, he sought foreign investment for industries, hospitals, and roads upon signing aid agreement with countries which Nepal had diplomatic relationships. The second five-year development plan, which was drafted at that time, also gained substantial support from donor countries.

However, BP was cautious to the repercussions of the foreign aid. He said,

Foreign aid in our situation cannot contribute the process of development; rather it creates a new class of people whose affluence would be asymmetrical to the general economic condition of the nation as a whole. The new class would have no economic roots in the country. It exists solely by manipulating the foreign aid through corruption, illegal trade etc. (Koirala, 2014, p. 121).
While favoring it, BP held the view that Nepal should not fully rely on foreign aid for its socio-economic transformation. Foreign aid alone could not be enough and cannot ensure sustainability of the country's development. $\mathrm{He}$ argued that Nepal's reliance on foreign aid could increase economic dependency and deteriorate nationality. BP held the view that the foreign aid could often be manipulated in the interest of those in power. As such, these views he held after 1970 while he was in opposition.

$\mathrm{BP}$ argued that foreign aid should be free from any terms and conditions that underrate the decision-making role of the recipient country. To avoid psychological uneasiness between receiving and the donating countries, BP proposed a neutral agency, such as UN, for channeling the aid. While addressing a 15th general assembly of the UN, December 1959, he said 'in an underdeveloped country the foreign aid should not come directly from the donor states, rather from the UN agencies' (Koirala, 2014, p. 103). This approach, on the one hand, could ensure foreign cooperation in development, on the other the underdeveloped country could feel independence and sovereign while receiving the aid.

\section{Tax}

BP Koirala's views on tax are that it is a source of national capital and means of equitable distribution of wealth in society. He said, 'the billionaires and rich people should pay tax. The poor cannot be best served unless rich pay the tax' (Basnet, 2017, p. 597). BP denied the system of land tenure that relieved the owner from tax. The tax-free land tenure system, for example, Birta, Jagir among others, was the root cause of inequality and injustice in agricultural society. He believed that the system of tax-free landholding should be abolished and brought into the tax circle.

As Premier in 1959, BP introduced a new tax system, called progressive tax, a tax system that imposes tax rate based on taxpayer's ability to pay. Low-income earners pay low tax rate in comparison to high-income earners, such as big landholders. He also declared property tax on private ownership. It entailed tax to the income of Royal family members besides the king, queen, and the crown prince. Private ownership such as Birta land, urban property, profit from the businesses, urban drinking water, and radio among others were brought under the system of property tax. However, the tax was reduced to low on the items such as consumer goods, goods produced by local industries and the import of crude raw materials needed for factories (Basnet, 2017 , p. 346). The objectives of imposing progressive and property tax were that these could be reliable sources to contribute to national capital and that they were equitable taxes, which could reduce income gap among social groups. Tax regime was the topmost priority of BP-led government's economic policy in 1959/60. 


\section{Land Reform}

BP Koirala raised land reform as political issue before organizing revolution against Rana oligarchy. BP continued to discuss this until the middle of the sixties. Until 1960s, country's land in majority belonged to the members of royal family, high-level officers, and those in higher political ladder. Majority farmers were landless, renters, sharecroppers, or small farmer (Pandey, 2009). As such, the land determined the social and economic status of the folks. The situation could create wider gulf between those having ownership to land and have's not. Being in majority, the small farmers, and landless dependents could be sharp political weapon to wage revolution against the Rana's authoritarian regime.

BP held the view that existing land ownership pattern is unequal and needs reform policy so that progressive social and economic transformation could be achieved. To BP, land reform entailed; a) freeing farmers from economic and social exploitation b) increasing land productivity c) generation of new economic opportunities, and d) abolishing inequality and injustices (Basnet, 2017). BP Koirala believed that land is a common property belonging to all. Therefore, state is responsible to the equitable distribution of land among its citizens.

Towards this direction, as Home Minister in Rana-Nepali Congress joint cabinet in 1951, BP proposed 'Birta Land Abolition Office'. Though the cabinet endorsed the act, it was not enacted because the government could not remain in office for more than one and half a month. The new administration lacked commitment and efficiency to adopt the new policies (Basnet, 2009). Later on 17 September 1959, during BP led-government, 'Birta Land Abolition and Land Tax Bill' was successfully endorsed. According to the land reform plan, maximum landholding in Tarai was 25 bigha, in Hill 85 ropani, and in Kathmandu valley, the ceiling was 25 ropani (Pyakuryal, 2015). By imposing a ceiling on land holdings, BP aimed to acquire the excess land and distribute that to the renters, sharecroppers, and landless petty farmers (Biswabandhu Thapa, Personal Interview, 2/3/2018).

\section{Decentralization: People's Participation and Development Planning}

BP Koirala's perspectives on decentralization and participatory planning emerged during the fifties and continued evolving until the late eighties. He anticipated full participation of people in all forms of governance, including local, regional, and central. The motive behind the scheme was to build people's capacity and ensure in them an ownership of the process of development. The method, which could propel people into the process, is decentralization. BP assumed that decentralization is the third pillar of democracy after parliament and independent court to ensure people's voices in the governance.
BP conceptualized decentralized system of governance at four levels. From the bottom to the top the four levels are; village panchayat, district panchayat, zones and central government which comprised the King, the government, parliament, and the Supreme Court. For the purpose of national development planning, he assumed five specific units (Fig. 1). They are: 1) Central government 2) Economic regions 3) Districts 4) Electoral Constituencies 5) Village Panchayats (local government) (Basnet, 2009, p. 540). The districts, electoral constituencies, and village panchayats are the decentralized units responsible to deliver the fruits of national development.

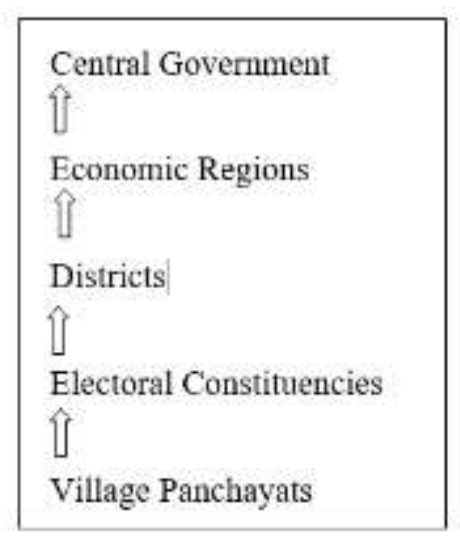

Fig 1: Development Units BP Envisioned for Planning Purpose

BP envisioned that district would act as the focal point of development and regional planning. The administration of the district is chaired by District Development Officer (DDO), who is responsible to formulate, plan and implement district development projects. According to Basnet (2017, p. 427) the responsibilities of the DDO were, a) to mobilize people for the participation in development activities in their area, b) to study and fix the priorities of development projects c) to identify the comparatively advantageous sectors to arrange investments d) monitoring of the development projects. Unlike Gandhi's village swaraj, an autonomous self-reliant local government, BP imagined that the villages must have a link and coordination with central government. BP believed that the local bodies must be technically and financially viable. Towards this end, he devised different policies for local development finance. During BP's tenure as prime minister, districts were provided with finances either 10 percent of total land tax (Malpot) or 40 thousand, whichever was higher. In the annual budget 1960, the amount was increased to NRs. 100,000 . BP held the view that local development activities should be solely controlled by village panchayats.

\section{Production and Productivity}

BP Koirala's views on economic production and productivity refer to the realm of socialism. BP believed that the question of equality in opportunities and distribution of 
resources that often confronts socialism is not just theoretically important but it needs dire practical considerations (Giri, 2009, p. 310). Because socialism is not a mere ideal or political slogan, rather, it has to walk along the crossroad of production and systems of production. BP believed that there should be a reciprocal relationship between equality and production systems, both are essential parts of socialism.

BP stated that equality should not be narrowed down, but it is to be understood in terms of both economic and political equality. A society to become politically equal, it requires a full functioning democracy. Economic equality is the question of productive capacity of society that is ensured by socialist pattern of economic and social institutions. BP held that a socialist state requires full blossoming of means of production and industrial progress.

Explaining the concept of production and equitable distribution, BP developed an anecdote about milk production in a village (Giri, 2009, p. 312). The agricultural village consisted of five thousand people. Its members farmed cows and milk them for their household needs. At some point, the total households produced fifty liters of milk per day. Now the milk was to be distributed equally to each members of the village. The amount being received was not more than a spoon per person. At the end of the story, BP asked; was the equitable distribution justice to the members of the village? Would everyone satisfy? He meant that producing low in quantity and distributing less than required is not an economic justice. The villagers could feel the justice if the village produces as much milk it could and distribute both equally and equitably. He believed that the system of distribution could only be justified with respect to the system of production.

Spotlighting the role of production, BP said that the highest aim of socialism rests on the sufficient production in the society, which could ensure distribution of the goods to its members according to their needs. Therefore, society needs to 'pay serious attention to developing its means of production in order to achieve the adequate produces' (Koirala, 2012, p. 24). He believed that a well-developed society is a society, which has well-matured means of production. 'The means should not benefit a few handicapped but larger section of the society' (Basnet, 2017, p. 199-200). He said 'full blossoming of means of production and industrial progress was a prerequisite to a socialist state' (Giri, 2009, p. 140). Thus, land, labor, technology, and capital were the means that needed to be developed in the first phase of socialism.

Development of land, according to BP, was solving the problems of unequal land tenure system, granting the land in the name of the farmers who plow it, abolition of the taxfree land ownership system, and management of farm inputs. Labor productivity depends on the education, health, salary, allowances, and training provided to the labor. Nevertheless, BP argued that basic human rights and freedom granted to the labor could enhance their productive capacity (Basnet, 2017, p. 35). The labor productivity was equally linked with industrial policies such as provision of labor union, equal pay and the nature of contract. During his premiership in 1960, Nepal's first labor act entitled 'Labor Act for Factories and Labors Working in the Factories, 2016' was promulgated (Basnet, 2017, p. 413). The third means of production BP discussed is technology. According to BP, improving technological efficiency means contextualizing it to improve technology's appropriateness in accordance with economic and geographic conditions of a society.

Govinda Adhikari (Personal Interview, 12/19/2017) held that BP's concept is appropriate technology, which means socially, economically, and environmentally fit machine. BP said that technology that was not accessible to the people due to their economic status would not suit Nepali economy. Foreign technology could yield low because farmers could not appropriately handle it. BP held the view that higher productivity of the economy best fits the local and labor-intensive technologies. Therefore, Nepal needed to rely on small and local technologies. Nonetheless, BP held these views during the eighties while in opposition. With regard to capital as the means of production, BP prioritized accruing national capital outsourced by tax and foreign aid.

\section{Control of the Means of Production}

According to BP, the fundamental assumptions in socialism were; a) economy is the cause of society's development, and b) society would control all the means of production available in the society (Basnet, 2017, p. 365). He explained that traditional economy could get modernize if the means of production could develop accordingly. With regard to the ownership of means of production, BP's idea was that society could control it. He stated that people could control their economic destiny by enriching their access to the means of production such as land, capital, technology, and labor. Control of national capital is possible through its elected representatives who could decide whether and how to apply the capital and other resources. BP said that the land, technology, and labor belonged to them who owned them. That said BP assumed democratic control of the means of production by the masses. It could be further ensured by the mass participation in decentralized system of governance.

\section{Conclusion}

BP Koirala's economic thinking emerged in the middle of the forties and evolved until the late eighties, the period when the global south remained a space in the bipolar global political economy. As such, economic ideas are mostly contextual and part of the political movements he himself 
waged at different timelines. They correspond and complement his political objectives, i.e. liberation, democracy, and socialism. In this sense, BP's economic thoughts narrowly define principles of economy and economic development. Nevertheless, they are people centered ideas with respect to political objectives and economic strategies.

Over the time, BP's economic perspectives had two fold objectives; mass mobilization for the sake of political goal and legitimization of political change and his leaderships for that change. For example, land reform looks like political weapon to counter Rana's authoritarian rule that had been suppressed millions of small farmers of their labor and productivity. Hence, land reform as an economic issue could demonstrate a strong political coalition in the middle of the forties when BP raised this issue first. Later, after 1960 while BP was in opposition, he hardly discussed land reform. Tax on property and abolition of tax-free land that BP's government implemented are also the elements of economy that could build coalition and legitimize democratic change.

BP Koirala's views on industrialization, decentralized planning, and foreign aid are an integral to his socialist orientation and part of the principles of Asian Socialist Conference. As such, BP's discussion on the significance and role of industrialization imply that he preferred statecapitalism; evidently, the system was popular during the fifties. BP's shifting views on the scale and size of industries after 1970s seem to be his criticism to the existing policies of the then government. That time he was in opposition and attempted to claim and legitimize his leadership by espousing alternative ideas. BP's thoughts on production, productivity, and technology also legitimize his opposition leadership. Amid cold war dynamics, BP aimed at decentralized planning system within a mixed economy. His ideas on foreign aid seem to be influenced by the principles of of Asian Socialist Conference and cold war setting and they tend to legitimize his intellectual and political leadership inside and outside Nepal.

Overall, more than the elements of economy and economic development, BP's explanations on industrialization, land reform, tax, foreign aid reveal the elements of political economy. Therefore, his economic ideas could influence policy perspectives of a government than models of economic theory.

\section{References}

Acharya N (2001) BP Koirala: Nepali congresska char aashak [BP Koirala and Four Decades of Nepali Congress] (In Nepali). Sambatsar.

Adhikari G (2014) Manawtabadiko samajbad [Socialism of a Superhuman] (In Nepali). http://samanantar.blogspot.com/2014/09/blogpost_9.html. (accessed on 4/20/2017).
Basnet P (2009) Nepali kangressko itihasko prarup [Foundation History of Nepali Congress] (Part One, In Nepali). Author.

Basnet P (2017) Nepali kangressko itihasko prarup [Foundation History of Nepali Congress] (Part Two, In Nepali). Author.

Chatterji B (1982) A portrait of revolutionary BP Koirala. Ankur Publishing House.

CIA (2016) Information report: Asian socialist conference activities for 1954. https://www.cia.gov/library/readingroom/docs/CIARDP78-00915R000500160005-4.pdf. (accessed on 15/5/2018).

Dettman PR (1974) Leaders and politics in 'Third World' Politics: Contrasting Approaches to Legitimacy. Comparative Politics. 6: 245-269.

Gandhi MK (1952) Rebuilding our villages. Nawajeevan Publishing Houses, Konark.

Giri P (Ed.) (2009) Bishweswor Prasad Koirala; Rajnitik abhilekh (in Nepali). Bidhyarthi Prakashan.

Government of Nepal (1962) Second Periodic Plan 1962-1965. National Planning Commission.

Joshi BL \& Rose LE (2007) Democratic innovations in Nepal; A case study of political acculturation. Mandala Publications.

Khadka N (2000) US Aid to Nepal in the Cold War Period: Lesson for the Future. Pacific Affairs 73: 77-95. http://www.jstor.org/stable/2672285. (accessed on 11/3/2017).

Koirala BP (2012) BP Koiralako adalatko bayan (In Nepali). BP Museum.

Koirala BP (2014) Democracy indispensable for development $\left(2^{\text {nd }}\right.$ ed). BP Museum.

Koirala BP (2015) Raja, rastriyata ra prajatantra (In Nepali). Jagadamba Prakashan.

Namita N (2014) Gandhi's Vision of Development: Relevance for 21 st Century. Indian Journal of Public Administration, 128, 59 (1). www.iipa.org.in/New\%20Folder/9-Nuti.pdf. (accessed on 11/4/2017).

Nepal C (2010) BP's economic thought. Pairavi Prakashan.

Nepal RM (2018). Alternative Development Perspectives and Trends in the Global South: With Special Reference to Social Democratic Thoughts of BP Koirala. Unpublished $\mathrm{PhD}$ Thesis, Tribhuvan University.

Pandey DR (2009) Nepal's failed development: Reflections on the mission and the maladies (revised 10th ed.). Nepal South Asia Centre.

Pyakuryal B (2015) Nepal's development tragedy: Threats and possibilities. Fine Print.

Rist G (2008) The history of development: From western origins to global faith. Zed, London. 
Rustow DA (1970) Philosophers and Kings: Studies in Leaderships. G. Braziller

Wriggins WH (1970) The Ruler's Imperative: Strategies for Survival in Asia and Africa. Columbia University Press.
Zande TVD (2017) A third world concept: The Asian socialist conference: Ideologies of neutrality, development and anti-imperialism in the laboratory of the 1950s. A Master Thesis on Colonial and Global History, University of Leiden, Netherland. 